\title{
The Students' International Community Service (ICS) as an Internationalization strategy for facing Global Challenges
}

\author{
Naeli Rosyidah ${ }^{1}$, Matin $^{2}$, Unifah Rosyidi ${ }^{3}$ \\ \{naelirosyidah@gmail.com ${ }^{1}$, naeli.rosyidah@mahasiswa.unj.ac.id ${ }^{1}$ \} \\ Education Management, Universitas Negeri Jakarta ${ }^{1,2,3}$
}

\begin{abstract}
The phenomenon of globalization affects economic, political, social and cultural aspects even educational aspects. With the impact of globalization, universities in the world try to respond to the challenges of globalization in various ways and international position of Higher Education Institutions (HEIs) in the global arena are increasingly emphasized. One of their efforts in responding to globalization is through internationalization. By internationalization of HEIs, there are many benefits obtained. One of the strategies used by Jendral Soedirman University is the implementation of Community Service Learning (ICSL). This article studies about the implementation of ICSL in Jenderal Soedirman University and its benefits. Some observations and interviews were conducted. The results show that ICSL is implemented through multidisciplinary field with many individual and institutional benefits
\end{abstract}

Keywords: ICS, Internationalization, Strategy, HEIs

\section{Introduction}

The phenomenon of globalization impacts on the economic, political, social and cultural sectors and even the education sectors. With the impact of globalization, universities in the world try to respond to the challenges of globalization in various ways. The dimensions and international positions of Higher Education Institutions (HEIs) in the global arena are increasingly emphasized [1]. One of their efforts in responding to globalization is doing internationalization of Higher Education (HE). To benefit from globalization, Higher Education Institutions in various countries attempt to make agreements and cooperations both regionally and internationally [2].

Internationalization of $\mathrm{HE}$ is understood as a concept and process of integrating the international dimension into the functions of teaching, research and service. This is because internationalization leads and is influenced by unexpected changes at various levels both institutions, communities and nations [3]. The most common definition used is the definition of internationalization by Jane Knight. Knight defines internationalization as the process of integrating an international, intercultural, or global dimension into the purpose, functions or delivery of postsecondary education [4]. Ota (2018) stated internationalization as a catalyst that encourages universities to reform themselves to respond to the demands of the global 
community. It means that the quality and vaues of internationalization of HEIs continues to be studied [5]

Globalization and internationalization are interrelated each other. Globalization is a process affecting internationalization as Knight said Internationalization is changing the world of education and globalization is changing the world of internationalization" [4]. The term and concept of internationalization first emerged in the 1990s. Previously, there had been a substantial research and practice tradition regarding the international dimension of higher education in general with the term international education, or activities reflecting international activities. Most of the terms used are curriculum related to international studies, global studies, intercultural education, peace education, multicultural education, or mobility related to studying abroad, education abroad, academic mobility, etc. De Wit (2013) added that over the past ten years, there have been new groups of terms debated related to the internationalization of higher education. Those terms are focused more to the delivery across the educational field as a consequence from the globalization impacts such as borderless education, cross-border education, global education, offshore education, and international trade of education services. In the 1990s the term 'internationalization' really took over the term 'international education'. This shift is a reflection of the growing importance of the international dimension in higher education and the transfer of a series of marginal programs and activities to a more comprehensive process [1].

Higher education institutions implement Internationalization as the top level in international relations because internationalization has been one of the most prominent phenomena in policies, practices and researches in higher education since the beginning of the twenty-first century [4] and a way to improve the quality of HEIs [2]. The more intense involvement with internationalization becomes increasingly important as the core mission of HEIs for the students, staffs, other stakeholders, and institution's needs. All higher education institutions face this reality depending on the institutions missions. Essentially, there is no best model or approach of internationalization to be adopted for institutions because the best model or approach is that fits the missions, values, practices and modes of operation of the institutions.

Essentially, there are some shifts and developments in the definition of internationalization. Acording to de Haan (2014) based on his analysis of several articles, there are three development stages in the term of internationalization [6]. First, there is a shift from an activity-focused to a strategy-focused perspective. Second, there is a broadening from the individual institutional level to the sector / national / regional level. Third, there is a development from fragmented studies from diversified perspectives to a synthetic view of internationalization.

Knight (2003) defines internationalization initially as "the process of integrating international or intercultural dimension into the teaching, research, and service functions of the institution". However, Knight renewed her definition which, according to her, is more complete, that is "the process of integrating an international, intercultural or global dimension into the purpose, functions or delivery of post-secondary education" [4]. The latter definition is considered more complete because it covers the national sector, new and varied education service providers, and different delivery methods. The term purpose, function, and delivery are more general than teaching, research, and service. Thus, the more general terms are more relevant for all sectors including the institutional level and the broader service providers of higher education. The term integrating specifically is used to show the process of instilling international and intercultural dimensions into policies and programs to ensure that the international dimension remains central and sustainable. The concept of purpose, function, and 
delivery is chosen to be used together. The word purpose refers to the roles and objectives of higher education for the state or mission of the institution. Function refers to the main element or task that characterizes the higher education system of a country or the institution itself. Usually this includes teaching, research, and service to the community. The concept of delivery is a narrower concept. This refers to the offer of educational programs or services both in and out the country by higher education institutions or other providers such as multinational companies who are interested in global delivery programs and services.

There are three themes related to internationalization of HE. Those are process, outcomes, and governance [7]. Accoring to Vardhan, process includes the various modes, and models to internationalize. The modes are concerned with program mobility, student, institution, academic mobility, etc. The models are the import and export model, the academic joint-venture model, the partnership model, and the foreign-campus model. Besides, there are mobility models which includes franchising, double or joint degrees, articulation models, and distance education. The main outcome of internationalization is considered by the institutions and the nation that helps in the advancement of knowledge and learning as the primary goal of all HEIs, alongside the political, economic and cultural rationale. The governance covers state and non state or internal and external actors should participate equally in the governance of HE.

One of the internationalization strategies is Students' International Community Service (ICS) or called Kuliah Kerja Nyata (KKN) Internasional. Historically, students' community service or also called community service learning rooted from a social-reform movements continued by educational reform movements of John Dewey at the University of Chicago in the early 1900s. Students' community service program is a potentially powerful means in linking academics and practices. They experience the real world and get benefits from the opportunity to connect their service experiences with their intellectual content got in their study[8]. Moreover, Yu and Road (2014) states that community service may become participatory learning practice that contributes to lifelong civic action [9].

International Community service is the name given to community service integration into student courses and in this case, international means the collaboration of foreign and local students. Hence, ICS can be seen as part of learning integrated with work. Most universities include services to the public in their mission statements. Its purpose is to help the community and students to acquire professional skills that they might need in the future [10].

\section{Method}

This article studies the Students' International Community Service (ICS) in Jenderal Soedirman University of Puwokerto, Central Java, Indonesia. Unsoed is a State University with a vision of being "Globally recognized university in the sustainable rural development and local wisdoms" in 2034. The purpose of this research focuses to describe how the ICS is implemented in Unsoed and what the benefits of ICS are. This research is expected to provide theoretical and practical benefits. Theoretically, the results of this study are useful for the development of theories and as one of the references related to ICS and internationalization strategy in Higher Education Institutions (HEIs). Practically, ICS can be beneficial in building international trusts to be adopted as one of internationalization strategy in HEIs.

This study focused on community service held by Jenderal Soedirman University and Ibaraki University of Japan. They had the community service in Serang Village, Purbalingga with the theme "Disseminating Appropriate Technology for Strawberry Seedling and Cultivation to Support Agro-Tourism in Serang Village, Purbalingga”. As Ibaraki University is a university of agriculture, the location of the ICS was in Serang Villae of Purbalingga famous 
with strawberry gardens. The students joining this community service especially Unsoed were from various faculty conducting different activities.

Some observations and semi structured interviews were conducted to the Ibaraki University supervisor, some students joining the ICS, the head of International Relations Office (IRO) of Unseod and the vice rector of academic affairs. The International Community Service (KKN internasional) was held in Serang Village of Purbalingga, Central Java annually. However, this study focused on the ICS program held in 2018.

\section{Results and Discussions}

International Community Service (ICS) is a kind of Internationalization strategy as ICS is a program collaborated between or among nations. The term internationalization has emerged in the education literature since the 1990s. Regarding the strategy of internationalization in HE, it should be contextualized in the internal context of the university, the university type, and its conditions on a national scale (de Wit, 2013). Strategies are also implemented according to their institutional, cultural and managerial contexts (Neale et al., 2018). So, there is no uniformity in internationalization strategy such as ICS because each university has its own characteristics.

The internationalization strategy implementation in the community service held by Unsoed and Ibaraki University students is categorized as program strategy. The definition of strategy has evolved since Chandler defined the strategy and according to them, the essence of the concept of strategy is the dynamics of the relationship between the company (organization) and its environment which requires action to achieve its objectives and / or to improve performance through the use of resources power rationally [11].

There are two types of strategies according to Jane Knight, namely program strategy and organizational strategy. Both types of strategies are mutually reinforcing and complementary so that they are needed in the process of internationalizing educational institutions [12]. The program strategy refers to initiatives that are academic in nature or related to teaching, learning, training, research, and directing or supporting the activities of institutions both at home and abroad. The organizational strategy includes policies, procedures, systems and supporting infrastructures that facilitate and sustain the international dimension of universities or colleges.

There are two terms emphasized in International Community Service those are international and community service. The International aspect is represented in the collaboration between Unsoed and Ibaraki University. Knight (2003) stated that International is the category for the relations among nations, cultures or countries [4]. Not only international aspect is shown in the ICS but also intercultural aspect is. Intercultural aspect is presented in the sharing and experiencing among Unsoed students, Ibaraki University students, and Community in almost all fields regarding their cross-culture. This cross-culture project shows that internationalization is really implemented in the community service by observation, experience, and knowledge share. The program implementation of ICS can be seen in the following table:

Table 1. The implementation of ICS through multidisciplinary fields

\begin{tabular}{lll}
\hline \multicolumn{2}{c}{$\begin{array}{c}\text { Community } \\
\text { Service Field }\end{array}$} & \multicolumn{1}{c}{ Example } \\
\hline Agriculture and & - & $\begin{array}{l}\text { Implementing screenhouse, hydroponics, organic fertilizers and pesticides } \\
\text { Environment }\end{array}$ \\
& - & $\begin{array}{l}\text { Observing Sloping land for strawberry cultivation and proposing possible } \\
\text { solution for the better production. }\end{array}$ \\
\hline
\end{tabular}




\begin{tabular}{lll}
\hline $\begin{array}{c}\text { Community } \\
\text { Service Field }\end{array}$ & & \multicolumn{1}{c}{ Example } \\
\hline Economy & - & $\begin{array}{l}\text { Strengthening economy for rural communities through the application of } \\
\text { packaging technology for strawberry } \\
\text { Creating food with strawbery toppings to sell }\end{array}$ \\
& - & Visiting traditional markets in Purwokerto \\
Education & - & Buying Indonesian esp. Javanese herbs and spices (rempah-rempah) \\
& - & Teaching how to make ninja origami to Primary School (PS) students \\
& - & Teaching foreign language to PS students \\
& - & Peer-teaching of agriculture technology uses \\
Public Health & - & Community education (educating farmers in applying screenhouse nd \\
& & hydroponics in improving strawberry quality \\
Culture & - & Experiencing and comparing household hygiene and health, etc. in \\
& & Indonesia and Japan \\
& - & Experiencing and comparing festivals and traditional cuisine/food in \\
& & Indonesia and Japan \\
& - & Experiencing wearing batik and kabaya (traditional costume) \\
& Observing and comparing religions and belief in Indonesia and Japan
\end{tabular}

From the table 1, it can be seen that the ICS was conducted integratedly from various fields including agriculture and environment, economy, education, health, and culture. This is in accordance with what Larson stated in his article that students' community service or social work education is meaningful when assisted by other disciplines. In order to do so, the institution must work actively in pursuing collaborative work in the service [13]. Larson added that ICS program should provide opportunities for students in other disciplines to participate with local communities and engage in humanitarian activities.

Moreover, in the ICS held by Unsoed and Ibaraki University, there are some benefits. First, because of the ICS, there is an engagement among students, community, and higher education institutions or universities. Su and Road said that students can obtain an individual's engagement in community relationships and interactions [9]. When the engagement happens, it becomes a true engagement (Clinton \& Thomas, 2009:52). In the common community service, the engagement is only among students (local), community (local), and university; however, in International Community Service (ICS), there are six interrelated engagement, namely (a) Local Students - Foreign Students, (b) Local and Foreign Students - Local Community, (c) Local Students - Foreign University, (d) Foreign Students - Local university, (e) Local University Local Community, and (f) Foreign University - Local Community.

Local students and foreign students are engaged in their activities because of the collaboration in planning, deciding, executing, and evaluating their program. Local and foreign students are engaged with local community because they serve local community for their better future regarding strawberry seedling, cultivation, and economy improvement. Besides, they are engaged with the community through educational practices. Local students and foreign university or Ibaraki University are engaged since the students of Ibaraki University joined the ICS and the same as foreign studets (Ibaraki University students) who are engaged with local university. The facilities and guidance provided by local university and foreign university give more engagement to the local community. They can collaborate and ask for guidance to the 
institutions in developing the economy, agriculture, education since two of higher education functions are to educate and serve community.

Second, ICS strengthens the university vision. Vision statement is a key of success in any organization or institution [14]. Vision gives direction of institution for the future and shows how the institution changes, where it goes, and gives motivation for the institution. As stated previously, Unsoed's vision is being globally recognized university in the sustainable rural development and local wisdoms. The implementation of ICS covers the development of rural community in Serang with modern agricultural technology, education, creative economy, etc.

Third, ICS develops international trust. The facilities and guidance provided by Unsoed as the Higher Education Institution entrust not only community in Serang Village but also international community since the ICS was conducted by both Unsoed and Ibaraki University. Trust as Tierney (2015) said is a two-party relationship in which an individual commits to an exchange before knowing whether the other individual will reciprocate [15]. In trust, there are four elements including communication, information, social, and cognitive trust [16]. In ICS, social trust is the most dominant.

Trust is also perceived as the basis for decision making in many contexts and the motivation to maintain long-term relationships based on cooperation and collaboration [16]. Moreover, ICS can lead to reciprocity in community service among higher education institution, community, and students experiencing the service to take action toward social change [17]. It is a mutual benefit for the students, the community and the university.

\section{Conclusion}

The International Community Service (ICS) is a community service implemented internationally as an internationalization strategy for the Higher Education Institution. International aspect is represented in the collaboration between at least local and foreign university. Its implementation can use multidisciplinary fields or integrated fields to be able to complete one another. Moreover, ICS has some benefits. First, it results an engagement among Local Students and Foreign Students, Local-Foreign Students and Local Community, Local Students and Foreign University, Foreign Students and Local university, Local University and Local Community, and Foreign University and Local Community. Second, ICS can strengthen University's vision because the ICS implementation is in accordance with the university's vision. Third, ICS can develop international trust. For the next study, it is recommended to explore more ICS from different higher education institutions and also see other benefits in its implementation and can find out to what extent ICS influence the engagement and international trust.

\section{References}

[1] H. De Wit, "Internationalisation of higher education, an introduction on the why, how and what," in An Introduction to Higher Education Internationalisation " Centre for Higher Education Internationalisation, " Centre for Higher Education Internationalisation (CHEI), Università Cattolica del Sacro Cuore, Milan, Italy All, 2013, pp. 13-46.

[2] T. Jibeen and M. A. Khan, "Internationalization of Higher Education: Potential Benefits and Costs," Int. J. Eval. Res. Educ. J., vol. 4, no. 4, pp. 2252-8822, 2015.

[3] S. Mertkan, I. Gilanlioglu, and S. McGrath, "Internationalizing higher education: from grand plans to evolving responses," J. Organ. Chang. Manag., vol. 29, no. 6, pp. 889-902, 2016. 
[4] J. Knight, "Updated Definition of Internationalisation," in International Higher Education, no. 33, 2003, pp. 2-3.

[5] H. Ota, "Internationalization of Higher Education : Global Trends and Japan 's Challenges," no. 12, pp. 91-105, 2018.

[6] H. (Helen) de Haan, "Internationalization: Interpretations Among Dutch Practitioners," J. Stud. Int. Educ., vol. 18, no. 3, pp. 241-260, 2014.

[7] J. Vardhan, "Internationalization and the Changing Paradigm of Higher Education in the GCC Countries," 2015.

[8] L. J. Vogelgesang and A. W. Astin, "Comparing the Effects of Community Service and ServiceLearning," pp. 25-34, 2000.

[9] Y. Su and S. Road, "Community Service as a Lifelong Learning Practice : Themes and Hypotheses," vol. 4, no. 4, pp. 219-226, 2014.

[10] I. Clinton and T. Thomas, "Business students ' experience of community service learning," 2009.

[11] G. A. Ronda-pupo and L. Angel, "Dynamics of the evolution of the strategy concept $1962-2008$ : A co-word analysis DYNAMICS OF THE EVOLUTION OF THE STRATEGY CONCEPT 1962 - 2008 : A CO-WORD ANALYSIS," no. February, 2012.

[12] J. Knight, "Internationalisation of Higher Education," in Quality and Internationalisation in Higher Education, OECD, 1999, pp. 13-23.

[13] G. Larson, "COMMUNITY SERVICE LEARNING_ What Does It Mean for Social Work Education," Can. Soc. Work Rev. / Rev. Can. Serv. Soc., vol. 25, no. 1, pp. 89-96, 2008.

[14] J. M. Bryson, Strategic planning for public and nonprofit organizations: A guide to strengthening and sustaining organizational achievement, vol. 34, no. 4. 2004

[15] W. G. Tierney, "Trust and Organizational Culture in Higher Education Trust and Organizational Culture in Higher Education," no. February, 2015.

[16] J.-H. Cho, K. Chan, and S. Adali, “A Survey on Trust Modeling,” vol. 48, no. 2, 2015.

[17] A. Petri, "Service-Learning from the Perspective of Community Organizations," vol. 5, pp. 93-110, 2015. 
